\title{
Attitudes Towards The Union in a Changing Economic Environment

\author{
-PETER BROSNAN
}

\section{INTRODUCTION}

All New Zealanders are affected by the depressed state of the economy and continuing price inflation. These issues are of concern particularly to members of the working class who face the possibility of unemployment while the real value of their earnings is being reduced. The dislocative effect of this turbulent economic environment would affect workers' attitudes on a whole host of issues but in particular attitudes towards their unions.

Studies of union members' attitudes towards their union are very few indeed although interestingly one of the existing pieces of research in this area dealt with a sample of New Zealand workers.? However, given the paucity of research of this type, we have no indication of the effect of economic conditions on workers' attitudes towards their unions nor do we have any theory to aid us in formulating hypotheses with respect to the relationship of these two variables. A priori, we would expect as economic conditions deteriorated, that the worker would turn to his union for protection and that his attitude would be a function of the degree to which the union was able to isolate the worker in the plant from the external environment

This article reoorts the results of a study of the manner in which a group of Dunedin workers changed their attitudes toward their union between November 1969 and 1971. The two years between the surveys, 1970 and 1971 , were particularly interesting as it was during this period that the symptoms of the present stagflation first became evident. The number of registered unemployed almost tripled during this period while the fate of inflation doubled. The change of 10.5 per cent in the consumer price index during 1970 was the highest rate of inflation experienced by New Zealand since 1951. The increased turbulence in the economy during this period presented a particularly suitable opportunity for studying changes in workers' attitudes.

\section{METHOD}

Two large factories were chosen and a third of the union membership in each were interviewed with respect to their attitudes towards their union. The two particular factories were chosen because, in addition to their providing ready access to a large group of workers, all the workers in both factories were members of the same union. The entire interviewing procedure was repeated two years later with another similar-sized sample. Thus it was possible to compare the union members attitudes at two distinct points in time.?

The period between the two surveys saw a reduction of employment in both factories. The number of workers in each was reduced by 12 per cent and overtime work-

- PETEA BAOSNAN is a lecturer at the Industrial Relations Centre, Victoria University of Wellington New Zealand. The author wishes to thank the union involved for their co.operation in this study and the editor of this journal for useful comments on an earlier draft.

$1-j$. Seldman, Attitudes of New Zealand Workers. Wellington, Industrial Reiations Contre, Victoria Uni. versity of Wellington, 1975. Other studies of aftitudes towards the union are.

N. F. Dufty. Indian workers' oplnions on trade union leadership. Journal of Industrial Relations. Vol 10, No. 2. 1968 , Dp. $146-153$

A. Johnston. Types of union members. Journal of Industrial Retations. Vol 18. No $2.1974 .00127-136$

H. Rosen and A. A. H. Rosen. The Union Member Speaks. Englowood Cliffs, Prentice-Hall. 1955;

L. A Saylos and G. Strauss. The Local Union: its Place in the Industrial Plant. New York, Harcourt

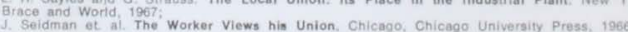

2 - The surveys were carried aut in conjunction with two other sfudies reported elsewhere: 1 . M. Howolls and $P$. Brosnan. The ability to predict workers' preferences: a research exercise. Human Relations. Vol 25. No, 3, 1972 PP, 265-28, and P. Brosnan. The ability to predict workers' preferences: further ovidence Human Relations. Voi. 28 , No, 6, 1975 , DP 519.541. 
ing. which had been common at the time of the first survey, had ceased almost entirely. Although wage rates had increased with inflation, the reduced hours of work were responsible for the workers concerned having a reduction in their take-home pay. ${ }^{3}$

\section{RESULTS}

The union members' satisfaction with the overall performance of their union is set out in Table 1. It will be noted that the majority were clearly satisfied with the union's performance at the time of both surveys and although the proportion of 'very satisfied' members reduced slightly between the surveys, the proportion of 'satisfied' members increased significantly.

TABLE 1

\section{OVERALL SATISFACTION WITH} THE UNION

1st Survey 2nd Survey

$\begin{array}{ccr}\text { Level of satisfaction } & \% & \% \\ \text { Very satisfied } & 10.0 & 9.1 \\ \text { Satisfied } & 51.2 & 57.3 \\ \text { Undecided } & 16.4 & 17.9 \\ \text { Dissatisfied } & 15.7 & 13.7 \\ \text { Very dissatisfied } & 6.7 & 1.9 \\ \text { X2 equals } 12.44 \quad P<0.05\end{array}$

The deterioration in the economic climate saw an increase in the proportion of union mambers attending meetings. Two general meetings of the union were held each year and the proportion attending both meetings increased from $9 \%$ to $13 \%$ and the proportion attending one meeting increased from $16 \%$ to $29 \%$. The satisfaction with meetings is shown in Table 2 and, although there is an increase in the proportion claiming to be satisfied with the meetings, the differences are not significant and it must be remembered that despite the increase in attendances by the second survey, more than $70 \%$ of members were still not attending meetings at all.
TABLE 2

\section{SATISFACTION WITH UNON MEETINGS}

1st Survey 2nd Survey

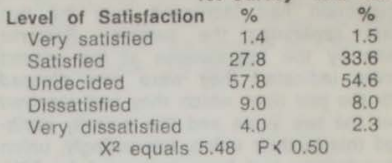

When quizzed specifically on their satisfaction with the union's handling of grievances, the majority in both surveys were satisfied and, as Table 3 shows, the proportion of satisfied members increased

TABLE 3

\section{SATISFACTION WITH GRIEVANCE HANDLING}

$\begin{array}{ccc} & \text { 1st Survey } & \text { 2nd Survey } \\ \text { Level of Satisfaction } & \% & \% \\ \text { Very satisfied } & 7.0 & 9.9 \\ \text { Satisfied } & 43.1 & 54.6 \\ \text { Undecided } & 30.1 & 22.5 \\ \text { Dissatisfied } & 13.4 & 9.6 \\ \text { Very dissatisfied } & 6.4 & 3.4 \\ X^{2} \text { equals } 23.21 & P<0.01\end{array}$

significantly from $50 \%$ to $65 \%$ while the proportion of dissatisfied members fell from 20 to $13 \%$. The proportion which was satisfied with the union's efforts at improving pay and working conditions was higher being $56 \%$ in the first survey and significantly higher at $78 \%$ in the second survey and, as can be seen in Table 4 , the proportion of dissatisfied members fell from 21 to $12 \%$.

TABLE 4

\section{SATISFACTION WITH GAINS IN PAY AND WORKING CONDITIONS}

\begin{tabular}{ccc} 
& 1st Survey & 2nd Survey \\
Level of Satisfaction & $\%$ & $\%$ \\
Very satisfied & 7.0 & 11.5 \\
Satisfied & 48.5 & 66.0 \\
Undecided & 23.4 & 11.1 \\
Dissatisfied & 16.7 & 10.3 \\
Very dissatisfied & 4.4 & 1.2 \\
X2 equals $54.77^{2}$ & P & 0.01 \\
\hline
\end{tabular}

3-The reduction in employment aiso meant a smalier number of workers in the second survey: the second sample size being 262 compared with 299 for the first survey. 


\section{DISCUSSION}

The results show two things: that the majority of the workers in the factories were satisfied with their union 4 and that their satisfaction had increased over the two years separating the surveys. Remarks made by the interviewees at the second survey indicated they were very pleased with the pay rises which they had received over the two years and the majority attributed this to their union. Interestingly, union subscriptions had been increased by $73 \%$ shortly before the second survey and although $63 \%$ of the membership considered the higher fees acceptable, $34 \%$, compared with $23 \%$ at the earlier survey, considered them high or very high. A further change between the two surveys was the introduction of a 'check-off' system of collecting subscriptions. It is sometimes argued that such a system reduces interest in the union: rather than the union being identified with the shop steward or other official, who collected the subscription, the union merely becomes a deduction from one's pay. There was no evidence from this study to indicate that the 'check-off' system had reduced interest in the union.

Tagliacozzo and Seidman have argued that the more favourable a member is towards his union. the more likely he is to attend meetings. 5 This proposition is certainly borne out by this study. Attendances at meetings and satisfaction with the union each increased over the period of this study. Despite the increased numbers at meetings, the proportion of workers attending was still lowe and a source of concern to the officers of the union. Some of the rank-and-file members who had never attended meetings expressed guilt feelings about this and some gave explanations or excuses. These ranged from the inconvenience of meeting times to the fact that they could not understand parliamentary procedure, that they were hesitant to speak at meetings, that they did not know when meetings were being held or that they were content with the status quo and thus could see no point in attending. Those who did attend made it clear that one of their reasons for attending was the uncertainty associated with inflation and the possibility of unemployment.

\section{CONCLUSION}

This research, conducted in an environment where the workforce was already satisfied with the performance of their union lound that, despite a hefty increase in union subscriptions and the introduction of a 'check-off' system, satisfaction with the union increased over a two-year period which saw a reduction in employment and an increased rate of inflation. The increased attendance at union meetings reflected the less favourable economic environment and the increased satisfaction appeared to be derived, in part, from the wage increases which had been gained in the period.

Thus it certainly would appear that during a period of economic decline, satisfaction with unions is a function of the extent to which the union protects its members from the economic environment. However. this proposition requires further testing. It would be useful to know how attitudes towards the union change when stagflation has persisted for a lengthy period. Does satisfaction with the union remain at the same level or does dissatisfaction with the overall state of the economy spill over into dissatisfaction with the union? Another relevant factor is the anti-union publicity which has grown out of the stagflationary situation. Does this 'poison' the ordinary union member's attitudes towards his union or does it have the reverse effect of driving him to the defence and support of his union? It would also be interesting to determine how the attitudes of union members

4-The study reported here was different in many respecis from Seidman's study of the attitudes of Niew Zeaiand workers. Seidman's study was concerned with the attitudes of members of different unions in four plants at a particular point in time. In contrast, this study was concerned with the atritudes of one union in two plants at two distinct points in time. Despite this, and despite differences in the questionnaires used the results of the studies are nol dissimilar See Seidman. Aftitudes of New Zealand Workers. OD. cit DD. 44-45, 65, 68:

5-D. L. Tagliacozzo and J, Seidman. A typology of rank-and-fite union members. American Journal of Sociology. Vol. 61. No. 6, 1956. pp. 546-553. The question of course is Do they attend because they are satistied or are they sassfied because they attend?

6-Although no lower than the proportions of members attending union meetings in the United Kingdom of the United States of America Cf H. A. Clego. The System of Industrial Relations in Great Britain. Blackwell, Oxtord, 1970. P 17 and Sayles and Strauss. OP. cit. PD 97-8. 
change when economic conditions are improving. Do the members become complacent during an economic upswing and does their satisfaction with the union diminish? The problem with conducting research of this nature is that it requires a commitment to carry out identical surveys with a considerable time gap between them. Further- more, there is no way of predicting in advance the changcs which may occur in the economy between the surveys. Nevertheless, if one or both of the surveys can be carried out in conjunction with some other project the cost would be less and. in any case, the benefits of such research would repay the effort.

\section{Towards Equal Opportunity Employment For Women in New Zealand \\ *AUDREY SHARP}

"We in this country have to live on our wits, and half the wits are in female heads, though one would never think so, looking at the way women are distributed throughout the labour market."

-Baroness Seear

\section{INTRODUCTION}

Women make up $50 \%$ of the total population in New Zealand and their numbers in the workforce are rapidly increasing. During the past forty years there has been a marked change in the composition of the labour force. The temale component has increased from $20 \%$ in 1926 to $32.5 \%$ in 1976. As the number of females in employment has increased, so has the composition of women engaged in employment also changed significantly. Married women are now entering the workforce in increasing numbers so that by $197655.8 \%$ of the female labour force was made up of married women. Despite their vastly increased numbers, however, women do not have access to every kind of employment but generally tend to work in a range of jobs that have largely been theirs traditionally. A far wider range of job opportunities is available to men only, both by convention and by the operation of legal restraints, and even in fields where women outnumber men, female workers almost invariably hold positions lower in status and remuneration. If women leave the workforce to have children and care for them, then they may lose not only their wages, but also their service bonuses and incidental benefits such as superannuation and accident compensation. Married women returning to the workforce are also forced to look for other jobs, since very rarely is their old job held open until their return. If women remain at work while their children are young they are often faced with an appalling lack of good child-care and after school facilities coupled with the reluctance on the part of many employers to concede variations in working hours.

\section{EMPLOYER ATTITUDES}

Traditional beliefs and continuing social norms have encouraged employers to treat women and men differently. Although sometimes this different treatment reflects an explicit policy, it more often represents the attitudes employers have towards women. While most employers will now admit that

- AUDREY SHARP is a masters student in political studies at the University of Auckland. The publication of this article marks the oflicial retirement trom the London School of Economics and Political Science of Baroness Seenr, author of the OECD Report on the Employment of Women. 